\title{
Biological Activity of Bambusa vulgaris Schrad. ex J.C. Wendl. (Poaceae)
}

\author{
S. R. Alencar ${ }^{1}$, M. A. P. Silva ${ }^{1}$, M. F. Figueiredo ${ }^{2}$, M. A. F. Santos ${ }^{1}$, M. E. M. Generino ${ }^{1}$, I. H. S. Torquato ${ }^{1}$ \\ \& M. K. M. Crispim ${ }^{1}$ \\ ${ }^{1}$ Universidade Regional do Cariri, Crato, Ceará, Brazil \\ ${ }^{2}$ Universidade Vale do Acaraú, Sobral, Ceará, Brazil \\ Correspondence: S. R. Alencar, Universidade Regional do Cariri, Crato, Ceará, Rua Cel. Antônio Luiz, 1161, 63 \\ 100 000, Brazil. Tel: 88-3102-1212. E-mail: sarinhalencar@hotmail.com
}

Received: February 27, 2015 Accepted: April 2, 2015 Online Published: May 15, 2015

doi:10.5539/jas.v7n6p150 URL: http://dx.doi.org/10.5539/jas.v7n6p150

\begin{abstract}
This study aims to evaluate the allelopathic activity of Bambusa vulgaris Schrad. ex J.C. Wendl., invasive species in an area of Cerrado in the Chapada do Araripe in Ceará. The treatments consisted of the aqueous extract in concentrations of 25,50,75 and $100 \%$ and a Control (distilled water), with five replicates containing 20 seeds each. The tests were carried out in the laboratory and in a greenhouse, using corn and beans as the test seeds. The parameters analyzed were number of germinated seeds, measurement of caulicle and radical length, occurrence of radicle necrosis and germination speed index (GSI). The results obtained from the laboratory bioassays on corn seeds indicate that the extract affected development of the seedlings, reducing caulicle growth and increasing radicle length, in addition to causing radicle necrosis. Regarding the bean seeds, there was a delay in the GSI, reduced caulicle growth and radicle necrosis. In the bioassay conducted in the greenhouse, for the corn seeds the extract inhibited germination and both caulicle and radicle growth, as well as delaying the GSI. When tested on the beans, the extract provoked reduction in the number of germinated seeds at the higher concentrations, delayed the GSI, reduced the radicle size and caused radicle necrosis. The allelopathic effects observed in the greenhouse were more significant, suggesting that environmental factors in conjunction with the action of the allelochemicals interfered more actively with the seed germination and seedling development of the receptor species.
\end{abstract}

Keywords: allelopathy, greenhouse, invasive species

\section{Introduction}

Certain areas are susceptible to invasion by exotic species which can lead to the elimination of native species. This type of biological invasion poses a serious problem to the functioning of ecosystems, primarily by threatening natural populations and causing the extinction of species in various environments all over the world. Invasive exotic species can not only survive and adapt to their new environment, but also start to exert dominance processes on the native biodiversity (Ziller, 2000).

Biological invasion by plant species is linked to various factors, such as efficient dispersion, greater longevity of seeds in the soil, premature maturity, long periods of flowering and fructification, adaption to degraded areas, reproductive efficiency and liberation of toxins capable of hindering the growth of other plants in the environment. This latter factor is the phenomenon known as allelopathy (Ziller, 2001).

Allelochemicals such as alkaloids, coumarins and phenols are produced through the secondary metabolism of plants and can be released through volatilization, leaching from aerial parts or decomposing material in the soil and also through radicle exudation (Macias, Galindo, Molinillo \& Cutler, 2003; Fujii \& Hiradate, 2007). Plants with this ability directly affect the species in their proximity and can cause the total extinction of more sensitive species in areas of natural vegetation. Therefore an increase in research focused on the alleopathic potential of different species considered as invasive is deemed necessary.

Currently, extensive areas of Cerrado are increasingly affected by the presence of invasive species, including Bambusa vulgaris Schrad. ex J.C. Wendl. (Poaceae) commonly known as bamburral. Research carried out by Schulz, Fortes, Boiago, and Machado (2010), Rios and Rosabal (2008), Rios, Rosales, Sosa, Torres, and Danme 
(2006) and Souza et al. (1999) confirms the allelopathic action of this species.

Field research reveals that B. vulgaris, like other bamboo species, proliferates on a large scale and can cause homogenization in the areas where it establishes itself; this could be an indication of its allelopathic activity. Given this evidence, the following work aims to evaluate the possible allelopathic potential of the aqueous extract of bamburral leaves on the seeds of Zea mays L. (corn) and Vigna sinensis (L.) Savi (bean), species considered as bioindicators.

\section{Material and Methodos}

\subsection{Preparation of the Brute Aqueous Exract (BAE) and Receptor Species}

To prepare the Brute Aqueous Extract - BAE, $200 \mathrm{~g}$ of fresh leaves of $B$. vulgaris were triturated in an industrial blender for 3 minutes in $3 \mathrm{~L}$ of distilled water. Next, the material was filtered using a glass funnel and cotton and the resulting liquid was centrifuged at $3.000 \mathrm{rpm}$ for 10 minutes in order to obtain the BAE concentrate (100\%). From this, dilutions of 25,50 and $75 \%$ were made. The Control was distilled water only.

The experiment was conducted in two environments; laboratory and greenhouse. Zea mays L. cultivar: Al Bandeirante p20 (corn) and Vigna sinensis (L.) Savi cultivar Setentão (bean) were used as receptor seeds.

The brute aqueous extract of $B$. vulgaris was analyzed for $\mathrm{pH}$ and osmolarity with the aid of a $\mathrm{pH}$ meter and an osmometer respectively.

The measurements of osmotic potential in the different concentrations were obtained in $\mathrm{mOsm} / \mathrm{kg}$ and converted to osmotic pressure (MPa) using the equation below (Larcher, 2004):

$$
\pi=-\mathrm{W} \times 0.00832 \times \mathrm{Tabs}
$$

Where, $\pi=$ Osmotic Pressure in MPa; $\mathrm{W}=$ Osmotic Potential in Osm $/ \mathrm{kg}$; Tabs - Absolute Temperature, expressed in Kelvins.

\subsection{Germination Bioassays in Laboratory}

For the laboratory test, the Brute Aqueous Extract of the studied species was used in the dilutions previously described, in addition to the Control. The experiment was conducted in Gerbox ${ }^{\circledR}$ boxes, with a substrate of two sheets of Germitest ${ }^{\circledR}$ paper on which the receptor seeds were placed. The treatments were applied in completely randomized experimental design, with five replicates each. For each replicate, 20 seeds were used, totaling 100 seeds per treatment.

In terms of the quantity of extract in its respective dilutions and the distilled water (Control), $13.5 \mathrm{ml}$ was added to the germination boxes of corn seeds and $16 \mathrm{ml}$ to the bean seeds, in accordance with the seed analysis rulebook (Agriculture Ministry [MAPA], 2009). The entire experiment was carried out in a in a BOD germination chamber at a temperature of $25^{\circ} \mathrm{C}$ and a photoperiod of $12 / 12$ hours for 7 days.

The variables measured were number of germinated seeds (seeds with a radicle protusion over $2 \mathrm{~mm}$ ), germination speed index (GSI) and caulicle and radicle root length of 5 seedlings chosen at random from each box.

\subsection{Germination Bioassays in Greenhouse}

For the greenhouse experiment, acrylic boxes specific for germination tests were filled with a substrate of washed river sand and vermiculite 1:1, (v/v). The volume of extract added corresponded to $70 \%$ of the substrate capacity area, as indicated in Seed Analysis Rules (MAPA, 2009). Following the placing of the substrate in the cells of the boxes, one seed was added per cell. Each treatment consisted of five replicates, each with 20 seeds, totaling 100 seeds per treatment. The experimental design was completely randomized. The experiment was performed over a period of 14 days.

The parameters of analysis for each receptor species were number of germinated seeds (seeds whose cotyledons emerged above the substrate surface), germination speed index and measurement of caulicle and radicle length of 5 seedlings chosen at random.

\subsection{Phytochemical Characterization}

To research the secondary metabolites, freeze-dried aqueous extract was used. The tests were carried out according to the method proposed by Matos (2009) with the identification of the secondary metabolite classes present in the extracts being performed by way of cascade chemical reactions after the addition of specific reagents. 


\subsection{Statistical Analysis}

The statistical analysis of all parameters was carried out using the program ASSISTAT version 7.6 beta. The means underwent analysis of variance (ANOVA) and subsequent analysis of polynomial regression, testing linear, quadratic and cubic models with curve fitting according to the statistical significance $(\mathrm{p}<0.05)$ of the coefficients of the model. The significance of the coefficients of the parametric equations of the factors being studied was performed using the coefficient of determination when this was greater than $70 \%$.

\section{Results and Discussion}

\subsection{Laboratory Bioassay}

In the bioassays carried out in laboratory, the F-test results of analysis of variance show significant effects at the level of $1 \%$ probability $(\mathrm{p}<0.01)$ for the variables of radicle length in corn seeds and of germination speed index in bean seeds. For the caulicle length, the significance was at the level of $5 \%(0.01 \leq p<0.05)$ (Table 1$)$.

Table 1. Summary of analysis of variance of germination (G) and germination speed index (GSI) of seeds, and caulicle length (CL) and radicle length (RL) of seedlings of Zea mays L. and Vigna sinensis (L.) Savi exposed to different concentrations of the Brute Aqueous Extract of leaves of Bambusa vulgaris Schrad. ex J.C. Wendl. in laboratory conditions

\begin{tabular}{lllll}
\hline \multirow{2}{*}{ Variation sources } & \multicolumn{4}{c}{ Mean squares for Zea mays (laboratory) } \\
\cline { 2 - 5 } Treatments & G & GSI & CL & RL \\
Residue & $0,16000^{\text {ns }}$ & $2,92266^{\mathrm{ns}}$ & $0,04038^{\mathrm{ns}}$ & $19,05642^{* *}$ \\
C.V. (\%) & 0,28000 & 3,04090 & 0,36813 & 4,29544 \\
\hline Variation sources & 2.71 & 4,99 & 24,55 & 12,07 \\
& \multicolumn{4}{c}{ Mean squares for Vigna sinensis (laboratory) } \\
\cline { 2 - 5 } Treatments & G & GSI & CL & RL \\
Residue & $0,50000^{\text {ns }}$ & $6,49108^{* *}$ & $3,22230^{*}$ & $6,97286^{\text {ns }}$ \\
C.V. $(\%)$ & 0,40000 & 2,10902 & 0,56323 & 4,94877 \\
\hline
\end{tabular}

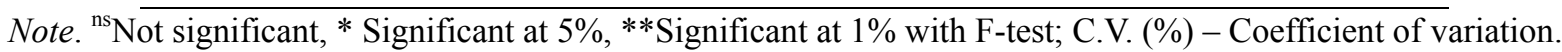

The Brute Aqueous Extract of fresh leaves of B. vulgaris did not present any significant difference in the germination ability of the seeds of $Z$. mays at any of the concentrations tested when compared to the Control (Figure 1). This shows that the different extract concentrations were not efficient in causing any allelopathic effect on the germination of these seeds. Such results support those obtained by Rios, Rosales, Sosa, Torres, and Danme (2006) with B. vulgaris, Guadua angustifolia Kunth and Dendrocalamus strictus Nees, the extracts of which did not affect the germination of $Z$. mays. Also, the extract in its various concentrations did not interfere with the germination speed index or the biometrics of the corn caulicles (Figure 1).

Despite the presence of secondary compounds potentially harmful to the process of germination, the concentrations and proportions were probably not significant enough to lead to a negative effect on the germination process, considering the emission of the primary root.

The radicle length of the corn seedlings exposed to the extract of $B$. vulgaris was affected in a positive manner as the extract concentrations increased. This increase was more significant in the radicles exposed to the $100 \%$ extract (Figure 1). Rios and Rosabal (2008), when researching the allelopathic effect of $B$. vulgaris, verified that the extract of this species also caused an increase in the length of the corn radicles. 


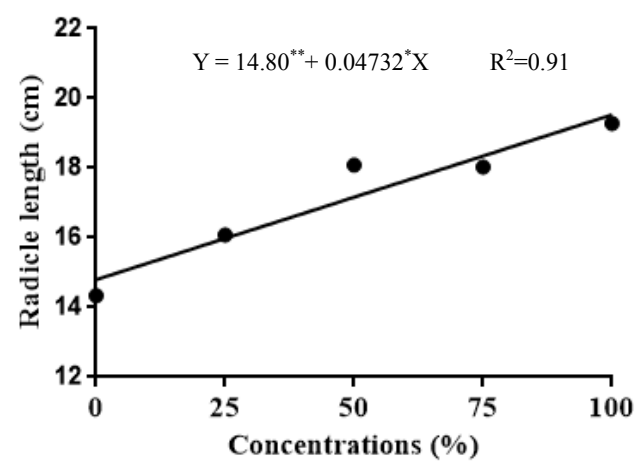

Figure 1. Mean of biometrics of corn seedling radicles exposed to different concentrations of the Brute Aqueous Extract of Bambusa vulgaris tested in laboratory

Note. $* *$ Coefficients significant at $1 \%$ * Coefficients significant at $5 \%$.

Regarding the bean seeds ( $V$. sinensis), it was confirmed that the extract of $B$. vulgaris did not interfere with germination. However, it interfered negatively with the germination speed index at all the concentrations, being most effective at $50 \%$ concentration (Figure 2).

According to Ferreira and Aquila (2000) germination is less sensitive to allelochemicals than seedling growth. However, it is often used in studies of allelopathy as its experimental quantification is quite simple; each seed represents a separate phenomenon of germination or non-germination. Therefore the allelopathic effect frequently shows in another process parameter (Ferreira, 2004), as for example in the germination speed index, as was observed in this study.

The bean seedlings exposed to the extract at $75 \%$ and $100 \%$ concentration showed a reduction in caulicle growth when compared to the Control, confirming that the greater the concentration, the greater the inhibitory effect on the growth of the aforementioned structure. This behavior is suited to a quadratic model (Figure 2). The results of this study diverge from those found by Rios and Rosabal (2008), where the extracts of B. vulgaris and Dendrocalamus strictus positively influenced the length of the bean epicotyl. This divergence could be due to the fact that in the study mentioned, leaves present on the surface of the soil were used in the production of the aqueous extract, whereas in our study fresh leaves where used. This could result in the presence of allelochemicals at different concentrations, affecting the epicotyl of the bean seedling differently. Therefore, according to Paula et al. (2014), the different results could be linked to the origin of the plants, the time of leaf or vegetable organ collection, since the presence and concentration of allelochemicals are affected by these factors.

The extract of the species under study did not affect the development of the bean radicles at any of the concentrations tested when compared to the Control.

(A)

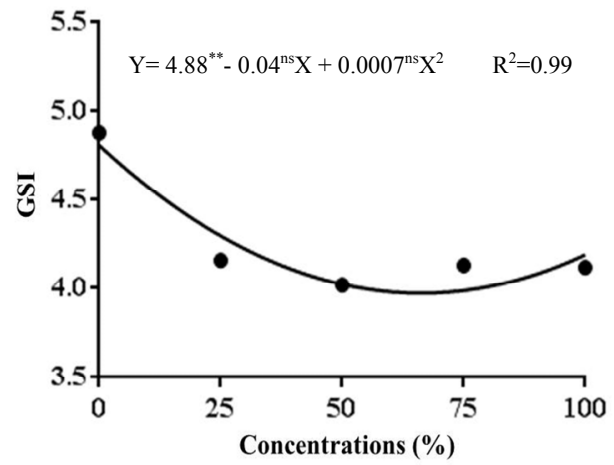

(B)

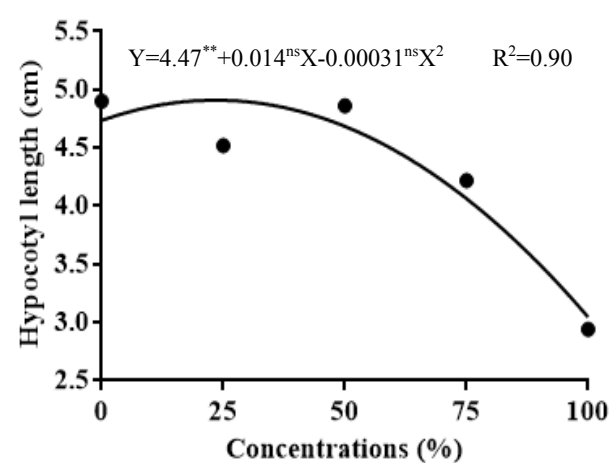

Figure 2. (A) Mean of Germination Speed Index (GSI) of bean seeds. (B) Biometric of bean seedling caulicles, exposed to different concentrations of Brute Aqueous Extract of Bambusa vulgaris tested in laboratory

Note. $* *$ Coefficients significant at $1 \%$ * Coefficients significant at $5 \%$. 


\subsection{Greenhouse Bioassay}

The F-test of the analysis of variance revealed significant effects for the corn seeds regarding the germination treatments, germination speed index, and caulicle and radicle length at $1 \%$ probability level. For the bean seeds the significant parameters were: germination $(\mathrm{p}<0.01)$, germination speed index and radicle length at $5 \%$ probability level $(0.01 \leq \mathrm{p}<0.05)$ (Table 2$)$.

Table 2. Summary of analysis of variance of germination (G) and germination speed index (GSI) of seeds, and caulicle length (CL) and radicle length (RL) of seedlings of Zea mays L. and Vigna sinensis (L.) Savi exposed to different concentrations of the Brute Aqueous Extract of leaves of Bambusa vulgaris Schrad. ex J.C. Wendl. in greenhouse conditions

\begin{tabular}{lllll}
\hline \multirow{2}{*}{ Variation sources } & \multicolumn{4}{l}{ Mean squares for Zea mays (greenhouse) } \\
\cline { 2 - 5 } & G & GSI & CL & RL \\
\hline Treatments & $34,64000^{* *}$ & $142,97739^{* *}$ & $2,42564^{* *}$ & $45,94422^{* *}$ \\
Residue & 4,32000 & 5,72115 & 0,12575 & 5,82384 \\
C.V. (\%) & 14,80 & 17,45 & 11,50 & 21.76 \\
\hline Variation sources & Mean squares for Vigna sinensis (greenhouse) \\
\cline { 2 - 5 } & G & GSI & CL & RL \\
\hline Treatments & $18,04000^{* *}$ & $52,23071^{*}$ & $0,35302^{\text {ns }}$ & $2,26438^{*}$ \\
Residue & 3,70000 & 6,24110 & 0,22806 & 0,95572 \\
C.V. $(\%)$ & 14,31 & 17,82 & 13,18 & 26,09
\end{tabular}

Note. ${ }^{\mathrm{n}}$ Not significant, $*$ Significant at $5 \%,{ }^{* *}$ Significant at $1 \%$ with F-test; C.V. (\%) - Coefficient of variation

Figure 3 shows the germination mean, Germination Speed Index, and Caulicle and Radicle Biometrics of the corn seeds when exposed to the extract of $B$. vulgais. From it we can observe that the cubic model was best suited to the variables under analysis.

The extract of $B$. vulgaris leaves significantly inhibited the germination of corn at all the concentrations tested, being most effective at 25\% concentration (Figure 3). Data obtained by Souza Filho (2006) shows germination inhibition in the seeds of Mimosa pudica, Senna obtusifolia, Pueraria phaseoloides and Brachiaria brizantha cv. Marandu when exposed to the extract of Paspalum maritimum leaves, invasive species belonging to the Poaceae. These results could indicate that the allelopathic interference is a mechanism belonging to the invasive species under study.

Various phenolic allelochemicals have the capacity to alter the biosynthesis of the principal constituents of the plant, which is reflected in its growth (Souza Filho \& Alves, 2002). This fact is justified when the chemical constitution of the donor plant contains phenols in its composition.

The germination speed index of the corn seeds was negatively affected at all the concentrations tested. A more significant reduction was observed in the seeds exposed to the BAE at $25 \%$ concentration (Figure 3). Similar data was obtained by Sonego, Cuzzi, Villani, Reddo, and Santos (2012) on testing macerations of Tanzânia grass on corn, having confirmed a reduction in the germination speed. The delayed germination could represent a disadvantage for the seeds in the field as they would be exposed to pathogens such as fungi, environmental factors and predation for a longer period (Oliveira, 2003).

When compared to the Control, a reduction in growth of the caulicle of the corn seedlings exposed to the extract studied was observed at all concentrations, being greatest at $25 \%$ concentration (Figure 3 ). This date shows that it is likely that some chemical substance present in the extract has the capacity to diminish the growth of the aerial parts of the receptor species seedlings, characterizing a negative allelopathic effect.

Regarding the radicle length, the Brute Aqueous Extract of B. vulgaris at all concentrations significantly inhibited the growth and lengthening of the radicles of the corn seedlings, this effect being most evident in the radicles of seedlings exposed to the extract at $25 \%$ concentration (Figure 3 ). The growth of the root system is a decisive factor in the success of seedling development and as Cândido et al. (2010) states, biometric tests are important to determine the alterations that the test substances can cause in the seedlings. 
The analyzed variables of the maize seedlings were affected at lower concentrations of the extract $(25 \%)$, these data corroborate the studies by Souza et al. (2005) which found that at low concentrations the aqueous extract of Mikania glomerata Spreng. (Guaco) and Casearia sylvestris Sw. (Tea-of-buggy) caused decrease in germination and higher concentration promoted an increase of germination. Richardson and Williamson (1988) the action of allelchemical substances is not very specific. The same substance may produce different effects depending on the concentration and chemical composition of it in the donor plant extract.

The seeds and seedlings of corn are sensitive to allelochemicals of other invasive donor species, as shown in the work of Faria, Gomes Júnior, Sá, and Cassiolato (2009) where it was observed that the extract of Pinus leaves provoked a reduction in the length of the radicle and hypocotyl of corn, and in the research of Pires et al. (2001) on the effect of the extract of leucaena leaves, in field conditions, on corn seeds and seedlings where a significant reduction in their radicle length was noted.

According to Ferreira e Borghetti (2004) the growth of the seedling is more sensitive to allelochemicals than the germination is, since the direct action mode of the allelochemicals acts from the membrane linkage in the receptor plant (corn) or penetrates the cells, causing interference in the metabolism.

(A)

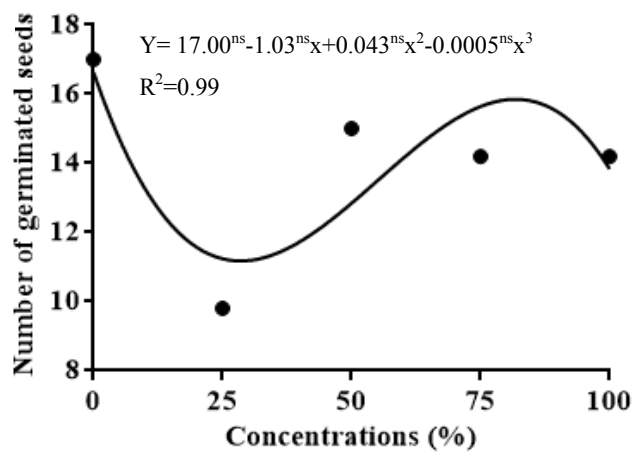

(C)

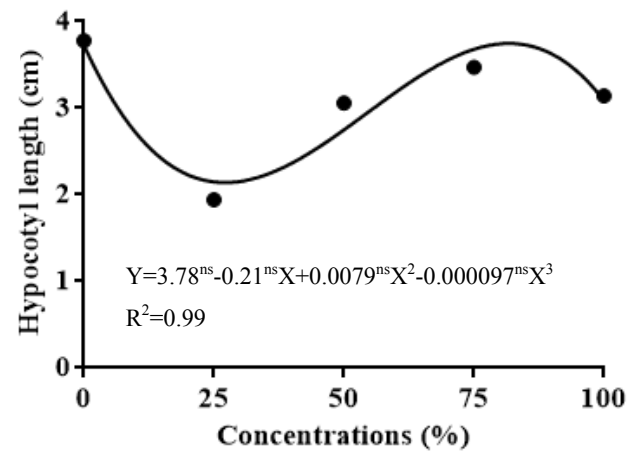

(B)

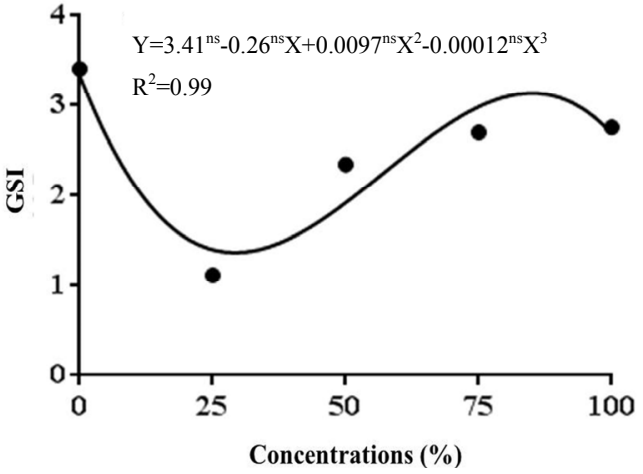

(D)

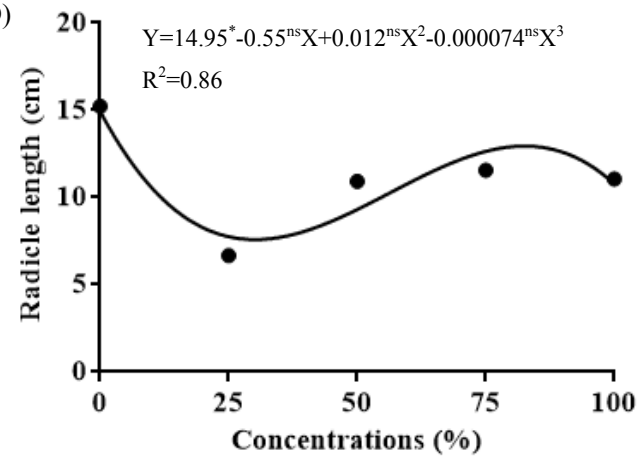

Figure 3. (A) Mean of Germination and (B) Germination Speed Index (GSI) of corn seeds. (C) Biometrics of caulicle and (D) radicle of corn seedlings, exposed to different concentrations of Brute Aqueous Extract of Bambusa vulgaris tested in greenhouse

Note. ${ }^{* *}$ Coefficients significant at $1 \%$ of probability. $*$ Coefficients significant at $5 \%$ of probability.

In the tests carried out on the bean seeds, the extract of B. vulgaris at 75 and $100 \%$ concentration provoked a significant reduction in the number of germinated seeds; for this, the linear model was best suited, with the number diminishing as the extract concentration increased (Figure 4). Souza et al. (1999) also observed a reduction in the germination of the receptor species seeds according to the application of the aqueous extract of Bambusa spp., with the greatest inhibition occurring at the 100\% concentration.

According to Araújo, Santana, and Espírito Santo (2011), the allelopathic action of metabolic compounds produced by donor species tested on the germination and development of bean seeds probably occurs through the chemical composition of this seed or through morphological aspects which facilitate the entrance of allelopathic substances in the interior of the seed. 
Regarding the bean seeds exposed to the extract of $B$. vulgaris, a delay in the germination speed index was observed at the higher concentrations ( 75 and $100 \%$ ); this was best suited to a quadratic model (Figure 4). The delay or the reduction in time spent for germination can be transformed into advantages or disadvantages in the field, especially when dealing with a species that has a short life cycle (Rodrigues, Artioli, Polo, Barbosa, \& Beijo, 2012). In the study of Dendrocalamus giganteus Munro extract, Schulz et al. (2010) obtained significant results when assessing the germination speed of lettuce seeds, thus highlighting the allelopathic potential of this exotic species of bamboo.

The extract of B. vulgaris in its various concentrations did not influence the caulicle development of the bean seedlings. The length of the radicles was affected in a significant manner by the BAE of the donor species, with the observance of a more pronounced reduction in radicle size in the bean seedlings exposed to the BAE at $100 \%$ when compared to the Control; this was best shown in a quadratic model (Figure 4). Corroborating with these results, Schulz et al. (2010) observed that the bamboo extract also did not statistically influence the length of the lettuce root. In general, the roots are more sensitive to allelochemicals than the aerial parts, even at low concentrations, as they are more exposed to the substances present in the substrate (Miró, Ferreira, \& Aquila, 1998).

(A)

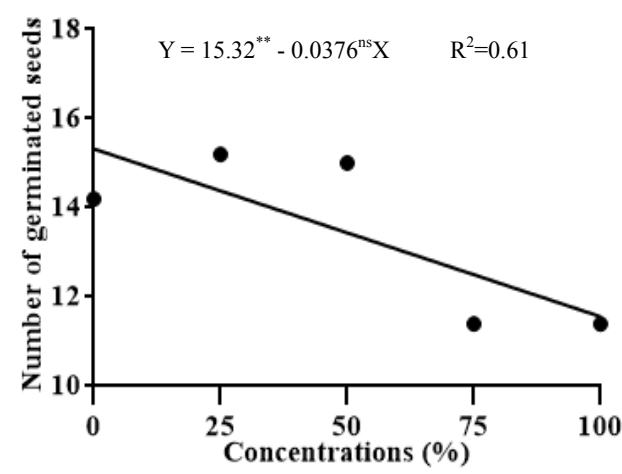

(B)

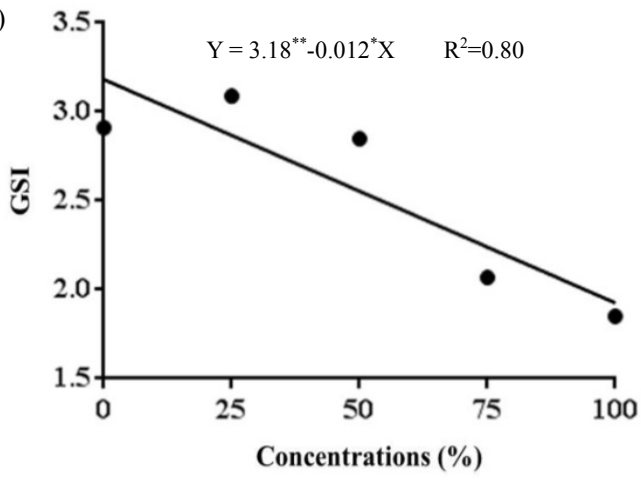

(C)

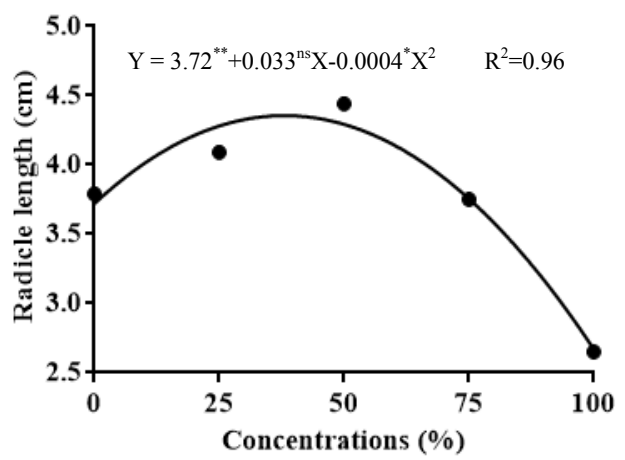

Figure 4. (A) Mean of germination and (B) Germination Speed Index (GSI) of bean seeds. (C) Biometrics of bean seedling radicles, exposed to different concentrations of Brute Aqueous Extract of Bambusa vulgaris tested in greenhouse

Note. $* *$ Coefficients significant at $1 \%$ of probability. $*$ Coefficients significant at $5 \%$ of probability.

The data relating to the germination and the growth of corn seedlings were affected at lower concentration (25\%), while the bean seedlings these inhibitory effects were dose dependent, being greater at higher concentrations. The difference in sensitivity shown by the two receptor species to the effects of B. vulgaris extract could contribute to a greater or lesser extent these effects. The biological activity of a given alelochemical depends on both the concentration and the boundary of the affected species response. The inhibition threshold for a given substance is not constant, but is closely related to the sensitivity of the receiving species, processes of plant and environmental conditions (Souza Filho, Vasconcelos, Zoghbi, \& Cunha, 2009).

The allelopathic inhibition results from the combined action of a group of allelochemicals which interfere with various physiological processes and depend on the extension of associated biotic and abiotic stresses, such as: 
temperature, humidity, radiation (Taiz \& Zeiger, 2004); in the laboratory such factors were kept under control whilst in the experiment carried out in the greenhouse such control was not maintained. These factors could have influenced the activation of the allelochemicals, thus confirming the results obtained in this research where the most significant negative allelopathic action was recorded in greenhouse conditions and not in the laboratory.

\subsection{Osmolarity and $\mathrm{pH}$}

The different concentrations of the aqueous extract of $B$. vulgaris show low $\mathrm{pH}$ variation, with values ranging between 5.7 and 5.9 (the first for $25 \%$ and the last for the higher concentrations). This is confirmed by Souza et al. (1999) who found a pH of 5.9 for the extracts of Bambusa spp.

The values of osmotic potential of the extracts were: $-0.03,-0.04,-0.07$ and $-0.1 \mathrm{MPa}(25,50,75$ and $100 \%$, respectively). These parameters are in accordance with acceptable norms for the germination and development of seedlings in bioassays on allelopathy (Gatti, Perez, \& Lima, 2004).

Germination as much as seedling growth is affected when the $\mathrm{pH}$ is extremely alkaline or extremely acidic (Roy, 1986), with detrimental effects observed in $\mathrm{pH}$ conditions less than 4 and more than 10 (Eberlein, 1987). Gatti, Perez, and Ferreira (2007) consider values of osmotic potential of no more than - $0.2 \mathrm{MPa}$ to be suitable for seed germination in allelopathic tests.

As such, it can be inferred that there was no interference from the $\mathrm{pH}$ and osmotic potential with the results obtained in this research, indicating that the action of the extract of B. vulgaris is due to allelopathic activity, showing inhibitory effects on the germination and growth of corn and bean seedlings, principally in the greenhouse tests.

\subsection{Phytochemical Analysis}

Through the detection of compounds of secondary metabolism in the fresh leaf extract of B. vulgaris, the phytochemical analysis revealed the presence of tannins, phenols, flavonoids, flavones, flavonols, xanthones and catechins. Corroborating the data found in this study, Valdés et al. (2010) confirmed the presence of quinones, phenols, triterpenes, lactonic compounds, alkaloids, steroids, amino acids, saponins and flavonoids.

Compounds such as tannins, cyanogenic glycosides, alkaloids, sesquiterpenes, flavonoids, phenolic acids and others stand out as classes of secondary metabolites with allelopathic activity (Tur, Borella, \& Pastorini, 2010), mainly inhibiting germination of seeds and growth of young plants, as well as causing the occurrence of abnormality in seedlings (Einhellig, 1995).

The phenolic compounds correspond to a class of secondary metabolites in which are found the majority of compounds indicated as having allelopathic activity (Rice, 1984), affecting the elasticity of the cell wall, besides blocking the mitochondrial respiration, for example (Weir, Park, \& Vivanco, 2004). The presence of these compounds in the extract of $B$. vulgaris is related to the found allelopathic effects. However, the isolation of the chemical constituents of this species is necessary to determine the compound responsible for the recorded allelopathic action.

\section{Conclusions}

1) In the laboratory, the extract of B. vulgaris at different concentrations acted more effectively on the development of the seedlings of de Z. mays and $V$. sinensis than on the germination and germination speed index;

2) In the greenhouse, the extract of $B$. vulgaris at different concentrations acted as much on the germination and germination seed index as on the development of the seedlings of $Z$. mays e $V$. sinensis. This effect is due to the combined action of the allelochemicals present in the extract and the environmental factors such as temperature and humidity;

3) The $\mathrm{pH}$ analysis of the aqueous extract of $B$. vulgaris leaves and the osmotic potential analysis showed that they are in line with the acceptable parameters for germination and seedling development;

4) The phytochemical analysis of B. vulgaris revealed the presence of tannins, phenols, flavonoids, flavones, flavonols, xantones and catequinas. The metabolites found in the species studied are probably related to the allelopathic action observed.

\section{References}

Araújo, E. O., Santana, C. N., \& Espírito Santo, C. L. (2011). Potencial alelopático de extratos vegetais de Crotalaria juncea sobre a germinação de milho e feijão. Revista Brasileira de Agroecologia, 6(1), 108-116.

Cândido, A. C. S., Schmidt, V., Laura, V. A., Faccenda, O., Hess, S. C., Simionatto, E., \& Peres, M. T. L. P. 
(2010). Potencial alelopático da parte aérea de Senna occidentalis (L.) Link (Fabaceae, Caesalpinioideae): Bioensaios em laboratório. Acta Botanica Brasilica, 24(1), $235-242$. http://dx.doi.org/10.1590/S0102-33062010000400030

Eberlein, C. V. (1987). Germination of Sorghum almum seeds and longevity in soil. Weed Science, 35(6), 796-801. http://dx.doi.org/10.1614/WS-09-0201

Einhellig, F. A. (1995). Allelopathy: Current status and future goals. In K. M. M. Inderjit Dakshini \& F. A. Einshellig (Eds.), Allelopathy: Organism, processes and applications. Washington, DC: American Chemical Society.

Faria, T. M., Gomes Júnior, F. G., Sá, M. E., \& Cassiolato, A. M. R. (2009). Efeitos alelopáticos de extratos vegetais na germinação, colonização micorrízica e crescimento inicial de milho, soja e feijão. Revista Brasileira de Ciências do Solo, 33, 1625-1633. http://dx.doi.org/10.1590/S0100-06832009000600011

Ferreira, A. G. (2004). Interferência: competição e alelopatia. In A. G. Ferreira \& F. Borghetti (Eds.), Germinação: do básico ao aplicado. Porto Alegre: Ed. Artmed.

Ferreira, A. G., \& Aquila, M. E. A. (2000). Alelopatia: Uma área emergente da ecofisiologia. Revista Brasileira Fisiologia Vegetal, 12(Edição especial), 175-204. http://dx.doi.org/10.1590/S0103-31312001000100009

Ferreira, A. G., \& Borghetti, F. (2004). Germinação: Do básico ao aplicado. Porto Alegre: Artmed.

Fujii, Y., \& Hiradate, S. (2007). Allelopathy: New concepts \& methodology. Enfield: Science Publishers.

Gatti, A. B., Perez, S. C. J. G. A., \& Ferreira, A. G. (2007). Avaliação da atividade alelopática de extratos aquosos de folhas de espécies de Cerrado. Revista Brasileira de Biociências, 5(2), 174-176.

Gatti, A. B., Perez, S. C. J., \& Lima, M. I. S. (2004). Atividade de extratos aquosos de Aristolochia esperanzae O. Kuntze na germinação e no crescimento de Lactuca sativa L e Raphanus sativus L. Acta Botanica Brasilica, 18(3), 459-472. http://dx.doi.org/10.1590/S0102-33062004000300006

Larcher, W. (2004). Ecofisiologia Vegetal. São Carlos: Rima Artes e Textos.

Macias, F. A., Galindo, J. C. G., Molinillo, J. M. G., \& Cutler, H. G. (2003). Allelopathy: Chemistry and mode of action of allelochemicals. Boca Raton: CRC Press. http://dx.doi.org/10.1201/9780203492789

Matos, F. J. A. (2009). Introdução à fitoquímica experimental (3 ed.). Fortaleza: EUFC.

Ministério da Agricultura (MAPA). (2009). Departamento de Produção Vegetal, Divisão de Sementes e Mudas. Regras para análise de sementes (p. 398). Brasília: LANARV/SNAD/MA.

Miró, C. P., Ferreira, A. G., \& Aquila, M. E. A. (1998). Alelopatia de frutos de erva-mate (Ilex paraguariensis) no desenvolvimento do milho. Pesquisa Agropecuária Brasileira, 33(8), 1261-1270. http://dx.doi.org/10.1590/S0100-204X2012000900002

Mizutani, J. (1999). Selected allelochemicals. Critical Review in Plant Science, 18(5), 653-671. http://dx.doi.org/10.1016/S0735-2689(99)00395-0

Oliveira, S. C. C. (2003). Alelopatia em Solanum lycocarpum St. Hil (Solanaceae) (Master's Thesis in Botany). University of Brasília, Brasília, Brazil.

Paula, C. C. da S., Cantelli, V. C. D., Silva, C. B. da, Campos, R., Miguel, O. G., \& Miguel, M. D. (2014). Atividade alelopática do extrato e frações das folhas de Dasyphyllum tomentosum (Spreng.). Journal of Basic and Applied Pharmaceutical Sciences, 35(1), 47-52.

Pires, N. M., Souza, I. R. P., Prates, H. T., Faria, T. C. L., Pereira Filho, I. A., \& Magalhães, P. C. (2001). Efeito do extrato aquoso de leucena sobre o desenvolvimento, índice mitótico e atividade da peroxidase em plântulas de milho. Revista Brasileira de Fisiologia Vegetal, 13(1), 55-65. http://dx.doi.org/10.1590/S0103-31312001000100007

Rice, E. L. (1984). Allelopathy (2nd ed.). New York: Academic Press. http://dx.doi.org/10.1016/B978-0-08-092539-4.50006-2

Richardson, D. R., \& Williamson, G. B. (1988). Allelopathic effects of shrubs of the sand pine scrub on pines and grasses of the sand hills. Forest Science, 34(1), 592-596.

Rios, C., \& Rosabal, M. (2008). Potencial alelopático de bambúes tropicales. Efecto sobre la germinación y el crecimiento de cultivos tropicales. Centro Agrícola, 35(2), 79-84.

Rios, C., Rosales, M., Sosa, R, Torres, S., \& Danme, P. V. (2006). Bambúes con marcados efectos alelopáticos. 
Biotecnología Vegetal, 6(2), 119-125.

Rodrigues, A. C., Artioli, F. A., Polo, M., Barbosa, L. C. A., \& Beijo, L. A. (2012). Efeito alelopático de folhas de bamburral [Hyptis suaveolens (L.) Poit.] sobre a germinação de sementes de sorgo (Sorghum vulgare Pers.), rabanete (Raphanus sativus L.) e alface (Lactuca sativa L.). Revista Brasileira de Plantas Medicinais, Botucatu, 14(3), 487-493. http://dx.doi.org/10.1590/S1516-05722012000300010

Roy, M. M. (1986). Effects of $\mathrm{pH}$ on germination of Dichrostachys cineria (L.). Wegth e Arn. Journal Tree Science, 5, 62-64.

Schulz, D. G., Fortes, A. M. T., Boiago, N. P., \& Machado, A. (2010). Alelopatia de bambu (Dendrocalamus giganteus MUNRO). Cascavel, 3(3), 31-39.

Sonego, E. T., Cuzzi, C., Villani, A., Reddo, A. R., \& Santos, I. (2012). Extratos alelopáticos de capim Tanzânia no desenvolvimento inicial de plântulas de milho. Revista Brasileira de Tecnologia Aplicada nas Ciências Agrárias, 5(2), 61-72. DOI: 10.5777/PAeT.V5.N2.05

Souza Filho, A. P. S. (2006). Interferência potencialmente alelopática do capim-gengibre (Paspalum maritimum) em áreas de pastagens cultivadas. Planta Daninha, 24(3), 451-456. http://dx.doi.org/10.1590/S0100-83582006000300005

Souza Filho, A. P. S., \& Alves, S. M. (2002). Alelopatia princípios básicos e aspectos gerais. Belém, BR: Embrapa Amazônia Oriental.

Souza Filho, A. P. S., Vasconcelos, M. A. M., Zoghbi, M. G. B., \& Cunha, R. L. (2009). Efeitos potencialmente alelopáticos dos óleos essenciais de Piper hispidinervium C. DC. e Pogostemon heyneanus Benth sobre plantas daninhas. Acta Amazonica, 39(2), 389-396. http://dx.doi.org/10.1590/1809-4392201305074

Souza, C. L. M., Morais, V., Silva, E. R., Lopes, H. M., Tozani, R., Parraga, M. S., \& Carvalho, G. A. (1999). Efeito inibidor dos extratos hidroalcoólicos de coberturas mortas sobre a germinação de sementes de cenoura e alface. Planta Daninha, 17(2), 263-272. http://dx.doi.org/10.1590/S0100-83581999000200010

Souza, S. A. M., Cattelan, L. V., Vargas, D. P., Piana, C. F. B., Bobrowski, V. L., \& Rocha, B. H. G. (2005). Efeito de extratos aquosos de plantas medicinais nativas do Rio Grande do Sul sobre a germinação de sementes de alface. Ciência Biológica da Saúde, 11(3/4), 29-38.

Taiz, L., \& Zeiger, E. (2004). Fisiologia vegetal. Porto Alegre: Editora Artmed.

Tur, C. M., Borella, J., \& Pastorini, H. L. (2010). Alelopatia de extratos aquosos de Duranta repens sobre a germinação e o crescimento inicial de Lactuca sativa e Lycopersicum esculentum. Revista Biotemas, 2(23), 13-22.

Valdés, A. F. C., Martínez, J. M., Lizama, R. S., Gaitén, Y. G., Rodríguez, D. A., \& Payrol, J. A. (2010). In vitro antimalarial activity and cytotoxicity of some selected cuban medicinal plants. Revista do Instituto de Medicina Tropical de São Paulo, 52(4), 197-201. http://dx.doi.org/10.1590/S0036-46652010000400006

Weir, T. L., Park, S. W., \& Vivanco, J. M. (2004). Biochemical and physiological mechanisms mediated by allelochemicals. Current Opinion in Plant Biology, 7, 472-479. http://dx.doi.org/10.1016/j.pbi.2004.05.007

Ziller, S. R. (2000). Estepe Gramíneo-Lenhosa no segundo planalto do Paraná: diagnóstico ambiental com enfoque à contaminação biológica (Doctoral Dissertation in Forest Engineering). Federal University of Paraná, Curitiba, Brazil.

Ziller, S. R. (2001). Plantas exóticas invasoras: a ameaça da contaminação biológica. Ciência Hoje, 30(178), 77-79.

\section{Copyrights}

Copyright for this article is retained by the author(s), with first publication rights granted to the journal.

This is an open-access article distributed under the terms and conditions of the Creative Commons Attribution license (http://creativecommons.org/licenses/by/3.0/). 